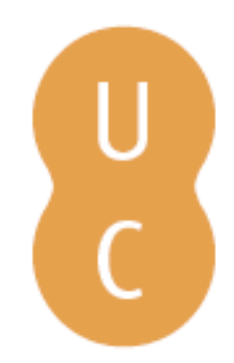

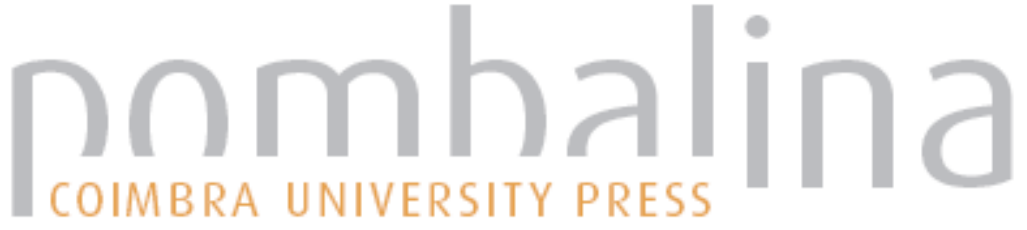

\section{Wind and slope effects on flame scaling in laboratory fires}

Autor(es): $\quad$ Finney, Mark A.; Forthofer, Jason A.; Grustrup, Torben P.

Publicado por: Imprensa da Universidade de Coimbra

URL

persistente: URI:http://hdl.handle.net/10316.2/44686

DOI: $\quad$ DOI:https://doi.org/10.14195/978-989-26-16-506_169

Accessed : $\quad$ 26-Apr-2023 12:13:58

A navegação consulta e descarregamento dos títulos inseridos nas Bibliotecas Digitais UC Digitalis, UC Pombalina e UC Impactum, pressupõem a aceitação plena e sem reservas dos Termos e Condições de Uso destas Bibliotecas Digitais, disponíveis em https://digitalis.uc.pt/pt-pt/termos.

Conforme exposto nos referidos Termos e Condições de Uso, o descarregamento de títulos de acesso restrito requer uma licença válida de autorização devendo o utilizador aceder ao(s) documento(s) a partir de um endereço de IP da instituição detentora da supramencionada licença.

Ao utilizador é apenas permitido o descarregamento para uso pessoal, pelo que o emprego do(s) título(s) descarregado(s) para outro fim, designadamente comercial, carece de autorização do respetivo autor ou editor da obra.

Na medida em que todas as obras da UC Digitalis se encontram protegidas pelo Código do Direito de Autor e Direitos Conexos e demais legislação aplicável, toda a cópia, parcial ou total, deste documento, nos casos em que é legalmente admitida, deverá conter ou fazer-se acompanhar por este aviso. 


\section{ADVANCES IN}

\section{FOREST FIRE RESEARCH}

\section{8}

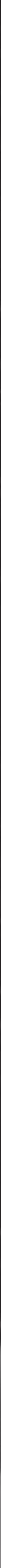


Short contribution - Fire Management

Wind and slope effects on flame scaling in laboratory fires

Mark A. Finney; Jason A. Forthofer; Torben P. Grustrup

USDA Forest Service, Missoula Fire Sciences Laboratory. 5775 Highway 10 West, Missoula MT, 59808. \{mfinney@fs.fed.us*\}

Keywords: Buoyancy, Flame Scaling, Wildfire Spread

\section{Introduction}

Ignition of wildland vegetation in wildfires is strongly dependent on convective heat transfer (Finney et al. 2015) because the fine size and sparse distribution of foliage and grasses enhances cooling by ambient air. This is sufficient to offset heating by thermal radiation until the flame front is close enough for impingement. Flame impingement on fuel particles occurs intermittently as flame parcels burst forward from the burning zone (Finney et al. 2015). These bursts and non-steady flame patterns are still poorly understood but may have genesis as buoyant or hydrodynamic instabilities (Tang et al. 2015, Tang et al. 2017). Prior experiments with wind-driven fires have revealed that ignition of fine fuel particles was caused by intermittent heating with average frequencies of $2-8 \mathrm{~Hz}$ [Finney et al. 2015, Tang et al. 2015). These frequencies exhibited Strouhal-Froude number scaling (Finney et al. 2015) such that lower frequencies occurred with longer flames but higher frequencies with stronger winds. This paper concerns results from additional experiments on flame characteristics in fires spreading up an inclined platform in the absence of wind.

\section{Methods}

A tilting 4 × $6 \mathrm{~m}$ platform, adjustable from $0-40^{\circ}$ slope angle was constructed for the purpose of studying upslope flame spread through engineered cardboard fuel beds (Figure 1). The surface of the platform was formed by a horizontal stack of cement-board lath (each $0.06 \mathrm{~m} 0.008 \mathrm{~m}$ ) held by a steel frame. Fuel consisted of cardboard cards with attached laser-cut particles of varying dimensions resembling a comb [4]. The spines of each comb were inserted into the slots between cement-board laths at varying spacing to produce fuel beds of vertically oriented cardboard particles.

Fires were ignited instantaneously along the downslope edge of the platform with a line of gasoline. A $60 \mathrm{~cm}$-long ramp without fuel allowed a boundary layer for induced air inflow to develop parallel to the platform before contacting the fuel bed (Figure 1). Flame fluctuations and spread rates were recorded with a linear array of 64 fine-wire thermocouples $(5 \mathrm{e}-5 \mathrm{~m})$, each separated by $0.03 \mathrm{~m}$. The thermocouple array extended upslope from a location $3 \mathrm{~m}$ from the ignition edge of the platform to allow flame spread to accelerate before measurements were taken. To measure hydrostatic pressure, a series of 16 pressure transducers were installed every $0.3 \mathrm{~m}$ with the pressure port located flush with platform surface. The pressure sensors were each co-located with a relatively large thermocouple $(0.127 \mathrm{~mm})$ to record flame arrival. Sampling frequency of all instruments was $500 \mathrm{~Hz}$ using National Instruments data logger.

\section{Results and discussion}

A total of 33 fire spread experiments on the tilting platform were conducted over a range of fuel and platform angles. Fuel properties and slope were varied to achieve different combinations of spread rate and intensity. Video showed the flame zone structure of fires on slopes to be qualitatively similar to those observed in wind driven fires (Figure 1). The leading edge of the flame zone displayed the same peak-and-tough structure produced by alternating upward and downward flows (Finney et al. 
2015). Spread rate varied from 0.004 to $0.155 \mathrm{~m} \mathrm{~s}^{-1}$. Flame length was estimated from video relative to graduated poles and varied from 0.3 to $3.0 \mathrm{~m}$, with spanwise wavelength between flame peaks 0.16 to $1.22 \mathrm{~m}$.

Flame contact with fuel particles forward of the ignition interface was seen to occur from intermittent horizontal bursts issuing forward from the trough-locations of the flame edge (Figure 1). These bursts originate from forward advection of coherent flame structures that first became visible near the rear of flaming combustion region (Figure 1a). The flame zone was composed of these concave parcels and suggests the topology of circulations in Raleigh-Benard (RB) cells for gasses. RB cells could result from the unstable stratification of low density flame gasses originating below denser ambient air. According to Koschmeider 1993, p 64, the circulation of gasses in RB cells is reversed from that of liquids, showing downward motion in the center. Thus, the visible flames trace a concave region of downflow within self-contained $\mathrm{RB}$ circulations that remain coherent as they advect forward through the flame zone. Instabilities become relevant to flame spread through their downstream bursts of flame into fresh fuels ahead of the ignition interface.

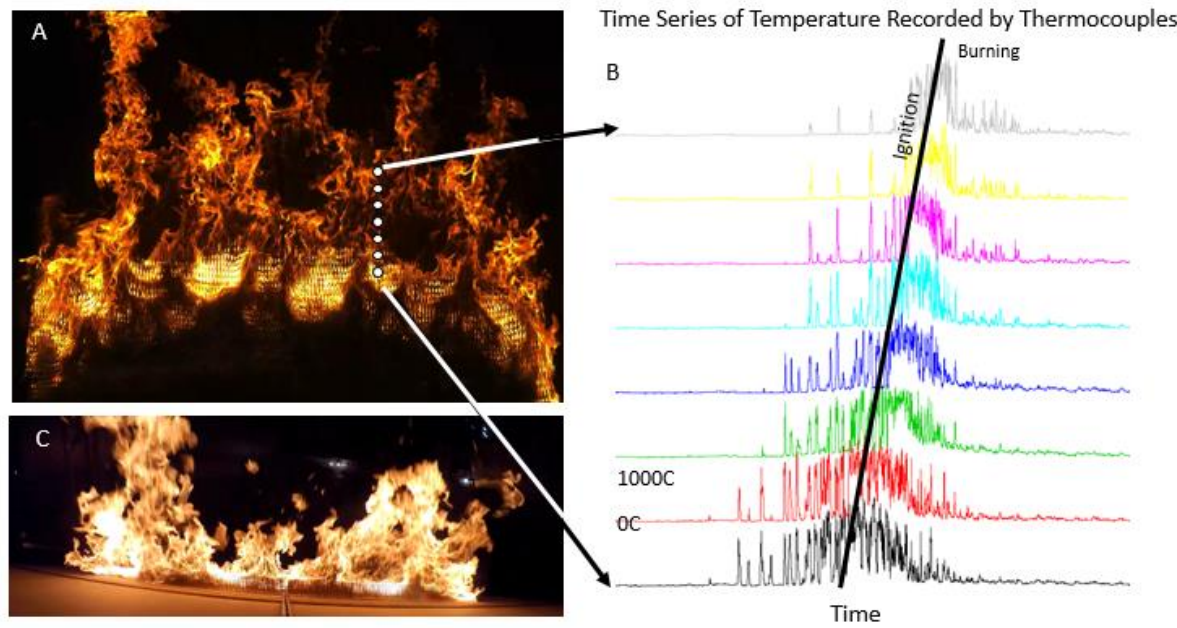

Figure 1 - Top view of flame zone for fire spreading upslope. (A) dish-shaped parcels and location of thermocouple rake that recorded temperature fluctuations from forward flame bursts as the fire approached. Temperature time series (B) shows flame intermittency before ignition, $(C)$ peak and trough structure as viewed toward the advancing flame front.

The coherent structure of flame bursts was revealed by their downstream travel estimated as the "zero correlation distance" forward of the ignition interface at the point where the temperature signals among thermocouples (Figure 1b) showed no correlation. This correlation distance suggested a nearly linear relation to flame zone depth for slope burns, but wind increased the horizontal deflection of flames in wind driven fires (Figure 2).

The predictive utility of these relations is not clear because fires spreading at near steady state (as these were) require the forward convective heating, by definition, to be sufficient to ignite fuels at the same rate as fuel burnout at the rear of the flame zone. It is suspected that the steady spread condition of fires on slopes evolves through some interplay of hydrostatic pressure and induced air inflow. This is evidenced by the observation that flames are vertical soon after ignition but eventually tilt toward the upslope direction as the flow-field develops. By contrast, flames in wind-driven fires are nearly horizontal at ignition. 


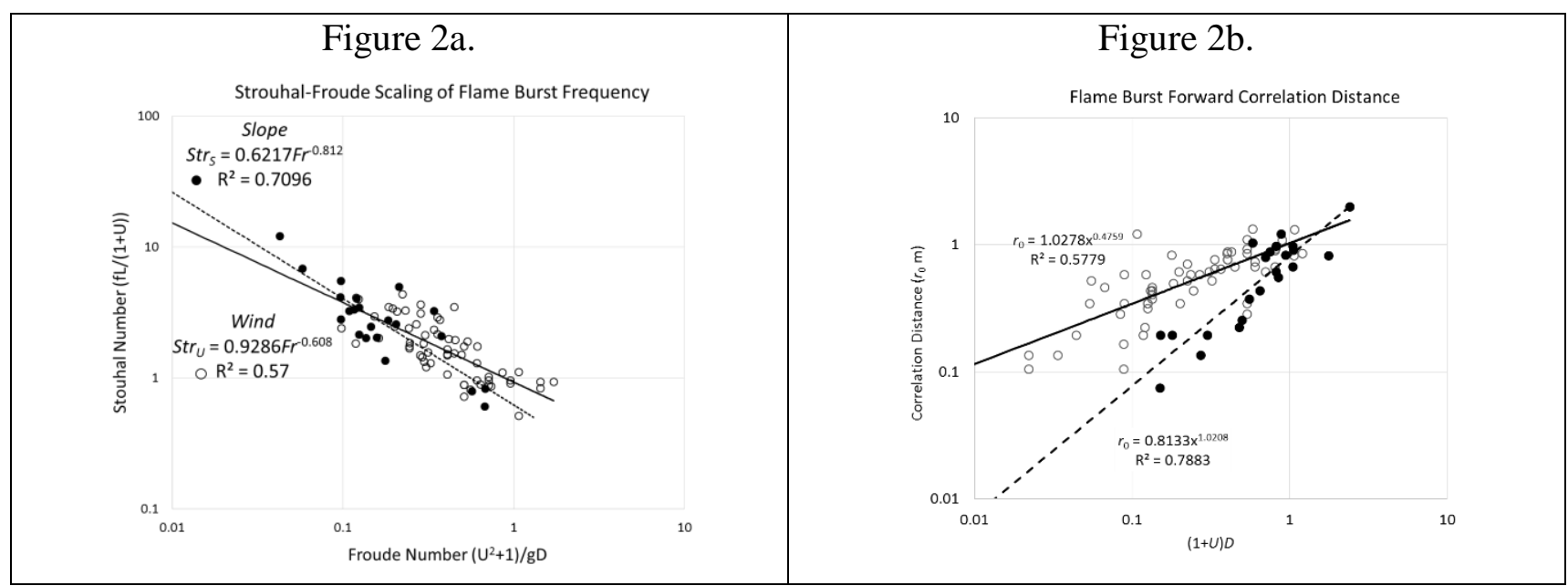

Figure 2. a) Flame burst frequency scaling between wind-driven fire and current slope-driven experimental fires using a Strouhal-Froude relation ( $f=$ frequency $(\mathrm{Hz}), \mathrm{L}=$ flame length $(\mathrm{m}), \mathrm{U}=$ wind speed $\left(\mathrm{m} \mathrm{s}^{-1}\right), \mathrm{g}=$ acceleration of gravity $\left(9.81 \mathrm{~m} \mathrm{~s}^{-2}\right)$, and $D=$ flame zone depth from ignition to trailing edge $(\mathrm{m})$. b) Forward flame burst distance (ro) reflects the length of convective heating ahead of the combustion zone (calculated as the correlation of downstream thermocouple temperatures) and depends upon flame zone depth $(D, m)$ for fires spreading upslope but also wind speed in wind driven fires $\left(U, \mathrm{~m} \mathrm{~s}^{-1}\right)$.

\section{References}

Finney MA, Cohen JD, Forthofer JA, McAllister, SS, Gollner MJ, Gorham DJ, Saito K, Akafuah NK, Adam BA, English JD (2015) Role of buoyant flame dynamics in wildfire spread. Proceedings of the National Academy of Sciences 112(32), 9833-9838.

Finney MA, Forthofer JA, Grenfell IC, Adam BA, Akafuah NK, Saito K (2015) A study of flame spread in engineered cardboard fuel beds, Part I: Correlations and Observations. Seventh International Symposium on Scale Modeling, Hirosaki, Japan, August 6-9, 2013. Pp. 71-83, In: Saito et al. (eds) Progress in Scale Modeling volume II, Springer.

Koschmieder EL (1993) Benard Cells and Taylor Vortices. Cambridge Monographs in Mechanics and Applied Mathematics. Univ. Cambridge.

Tang W., Gorham D., Gollner M., Forthofer J. Finney M. (2015) Forward pulsation behavior of winddriven line fires. 9th U. S. National Combustion Meeting.

Tang W, Gorham DJ, Finney MA, McAllister SS, Cohen JD, Forthofer JA, Gollner MJ (2017) An experimental study on the intermittent extension of flames in wind-driven fires. International Association of Fire Safety Science, https://doi.org/10.1016/j.firesaf.2017.03.030. 